\title{
"The Female Artist as an Icon of National Modernization: The Phenomenon of Lesia Ukrainka in a Comparative Perspective" (International Conference)
}

Reviewed by: Olha Polishchuk

Source: Kyiv-Mohyla Humanities Journal 8 (2021): 212-215

Published by: National University of Kyiv-Mohyla Academy

http://kmhj.ukma.edu.ua/ 


\title{
“The Female Artist as an Icon of National Modernization: The Phenomenon of Lesia Ukrainka in a Comparative Perspective" (International Conference)
}

\author{
Reviewed by Olha Polishchuk \\ Petro Mohyla Black Sea National University
}

2021 marked the 15oth anniversary of the birth of Lesia Ukrainka. She has become a kind of brand of Ukraine, the perception of her works having influenced the formation of a model of Ukrainian national identity. The international online conference, "The Female Artist as an Icon of National Modernization: The Phenomenon of Lesia Ukrainka in a Comparative Perspective" focused on two major themes: the relevancy of Lesia Ukrainka's European connections for Ukrainian and for other literatures, and female creativity as a factor in the modernization of culture.

The conference was held on October 13-16, 2021. Conference organizers focused on addressing such questions as: Lesia Ukrainka's works in English and Spanish; the reinterpretation of Lesia Ukrainka's cultural and literary priorities and her model for the modernization of Ukrainian identity; the writer's involvement in the ideological and political contexts of her era; and the leading role of the writer in the emergence of a new modernist drama. Additionally, the deconstruction of Lesia Ukrainka's image as presented in Soviet times was also a priority.

The conference was organized by the Association of Hispanists of Ukraine, the National University of Kyiv-Mohyla Academy, Petro Mohyla Black Sea National University, and the New Ukrainian Academic Community (NGO). Partners of the conference included the Ukrainian Fulbright Circle (NGO) and the Embassy of the Kingdom of Spain in Ukraine.

Thirty scholars from Ukraine, the United States, Great Britain, Spain, Italy, Israel, Portugal, and Taiwan engaged in intensive 4-day conversations focusing on the following areas: the representation of female creativity in the works of Lesia Ukrainka and in Ukrainian, Hispanic, and other world literatures; Lesia Ukrainka's ouevres and women's writing as a theoretical literary issue; Lesia Ukrainka and other female artists in popular iconography (visual imagery, monumentalization, advertising); representations of female artists in cinema and other audio-visual arts. I want to emphasize that this project was unique, as conference talks were delivered in English and Spanish, in addition to Ukrainian. This made it possible to reach a wide audience. Conference proceedings in the form of recorded videos can be found here: https:// www.facebook.com/UkrainkaConference21/.

The conference's opening day featured welcoming words by Oleksandr Pronkevich (President of the Association of Hispanists of Ukraine, Dean of the Faculty of Philology, Petro Mohyla Black Sea National University), Silvia Josefina Cortés Martín 
(Ambassador of the Embassy of the Kingdom of Spain in Ukraine), Jessica Zychowicz (Director of the Fulbright Program in Ukraine), Roman Veretelnyk (Head of the Department of Literature, National University of Kyiv-Mohyla Academy).

On October 13, keynote speaker, writer Oksana Zabuzhko, presented a talk entitled "Killing Don Juan: Modernism, Feminism, Nationalism (The Stone Host)." The researcher spoke on a female incarnation of the myth in the drama The Stone Host. She also offered an interpretation of Lesia Ukrainka's adaptation of the myth, which presents Don Juan as a man twice defeated by women. Emphasis was placed on the writer as a key figure in the development of both national and European feminist thought. Oksana Zabuzhko stressed that Lesia Ukrainka is a writer of the first magnitude, without whom the history of European literature of the 2oth century is incomplete.

A logical continuation of Oksana Zabuzhko's presentation was a panel devoted to a comparative analysis of Lesia Ukrainka's work in the context of other female artists in modernist literature. Speakers analyzed Lesia Ukrainka's works, concentrating their attention on a myriad of questions pertining to questions of gender in literature. The first day of the conference was summed up in a networking session entitled "Ukrainian Gender and Feminist Studies in a Global Context." The forum provided a platform for lively discussion among conference participants.

The second day of the conference, October 14, was begun by Vira Aheieva (National University of Kyiv-Mohyla Academy), with a talk entitled "Lesia Ukrainka's Epistolary Autobiography: A New Woman and Her Time." The researcher made an important contribution toward the rethinking of the creative phenomenon of Lesia Ukrainka on the material of her epistolary heritage. Vira Aheieva stressed that the writer's 12-volume collected works, published in 1970, and the 14-volume publication of 2021 contain completely different images of the author. In the first instance Lesia Ukrainka is presented as a revolutionary, social democrat, and collector of folklore, and in the second, she appears as a Ukrainian intellectual and modernist.

The second keynote speaker, Oleksandr Pronkevich, also emphasized Lesia Ukrainka's high intellectual level. A researcher of Spanish literature, he used an imagological approach to analyze how Lesia Ukrainka presented images of Spain in her works. Oleksandr Pronkevich concluded that the hetero-image of Spain in the works of Lesia Ukrainka is complex and contradictory. Roman Veretelnyk's talk about Lesia Ukrainka's work in English translations focused on their early reception in the English-speaking world. English translations of Lesia Ukrainka and her works presented both her and Ukraine to an audience not very aware of either, and were instrumental in contributing to an understanding of the writer and her country and culture.

The conference's Spanish-speaking contributors made it possible to consider the figure and work of Lesia Ukrainka in the broader context of Spanish and SouthAmerican literatures. Researchers focused on the issue of a comparative approach in 
the study of subjects, images, and motifs in the works of Lesia Ukrainka, Miguel de Unamuno, and Carmen de Burgos.

Keynote speakers on October 15 included Assunta Polizzi (The University of Palermo): “The Literary Feminine in María Zambrano's Thought”; Ruth Fine (The Hebrew University of Jerusalem): “The Representation of Women's Creativity in the Work of Cervantes"; and Eulalia Piñero Gil (The Autonomous University of Madrid): "Writing is Power: The Stories of Emilia Pardo Bazán and Kate Chopin from a Comparative Perspective." These scholars were united by the theme of women and their role in the creation of literature.

On the same day, Martha Bohachevsky-Chomiak (Taras Shevchenko Scientific Society, New York), presented a talk on Lesia Ukrainka. The distinguished researcher focused on the role of the Kosach family, in particular Olena Pchilka and Lesia Ukrainka, in the development of Ukrainian feminism.

A logical continuation of these presentations took place in a discussion panel entitled "Women Writers in Canon Formation." Ukrainian and American researchers discussed female writers (including Lesia Ukrainka) who were instrumental in redefining the patriarchal literary canon in modernist literature.

Part of the theme of feminism of that day featured a presentation of her book Superfluous Women: Feminism, Art, and Revolution in Twenty-First Century Ukraine (Toronto: University of Toronto Press, 2020), by Jessica Zychowicz. She spoke on how modern Ukrainian women realize their creativity in the visual arts. The book is intended to present 21st century Ukrainian history (politics, society, the arts) to an international audience.

The final day of the conference was opened by Maksym Strikha (Kyiv Taras Shevchenko National University), a noted researcher and translator, who is the editor of volume 8 of Lesia Ukrainka's 2021 14-volume collected works. In his talk on Lesia Ukrainka as a translator, Maksym Strikha outlined the thematic and stylistic directions of Lesia Ukrainka's translations, noting that Lesia Ukrainka understood the special role of her own translations, intending to "bring Ukrainian literature into the circle of other world literatures."

The final day of the conference was rich in a number of informative talks. Conference organizers presented 3 discussion panels in thematic areas: Lesia Ukrainka's work in foreign language translations, her innovations in dramaturgy, and female artistry in the audio-visual arts. Issues involving the translation of Lesia Ukrainka's works into Spanish, English, and Chinese were also discussed. Spanish-speaking researchers presented their interpretations of Lesia Ukrainka's dramatic works Cassandra and The Stone Host. Women's presence in cinema and the media was also discussed.

In summary, conference participants agreed that the figure of Lesia Ukrainka acts as a kind of Ukrainian ambassador to the Western world. The writer merits recognition for not only having made a major contribution toward the modernization 
of Ukrainian literature, but also for her unique contribution to all of European modernist literary thought and practise.

The international online conference "The Female Artist as an Icon of National Modernization: The Phenomenon of Lesia Ukrainka in a Comparative Perspective" transpired as a significant event of international scale. The online format of the conference helped bring together leading Lesia Ukrainka scholars from across the world. The conference Facebook page was visited by more than 40,0oo users. 574 followers watched live presentations. At the time of writing, the number of participants who have watched conference video proceedings has reached almost 4,ooo. I am glad to have had the opportunity to be part of this important event. 